Dept. of Food Hygiene,

Fac. of Vet. Med., Assiut Univ.

\title{
PREVALENCE OF CLOSTRIDIUM SPECIES IN CONCENTRATED AND DRIED MILK
}

(With 4 Tables)

By

A. ABDEL-HAMEID AHMED; ENAS EL-PRINCE; AMAL A. ABDEL-HALEEM* and MANAL M. AMIN*

* Assiut Animal Research Institute

(Received at 16/9/2011)

$$
\begin{aligned}
& \text { مدى تواجد عترات الكلوستريديم فى اللبن المركز واللبن الجاف } \\
& \text { أحد عبل الحميل أحدد ، إيناس البرنس ، آمال على عبل الحليم ، }
\end{aligned}
$$

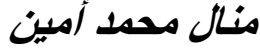

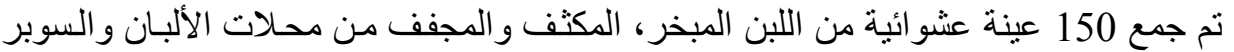

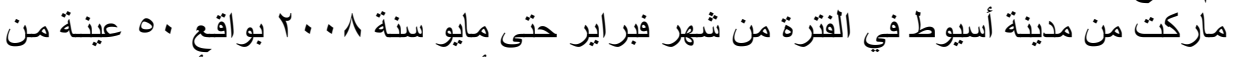

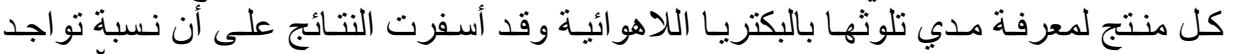
X ، Clostridium species

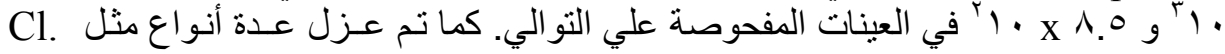
ramosum, $\mathrm{Cl}$.perfringens, $\mathrm{Cl}$. difficile, $\mathrm{Cl}$. innoculum, $\mathrm{Cl}$. septicum, $\mathrm{Cl}$. novyi type A, Cl. cadaveris, Cl. subterminale

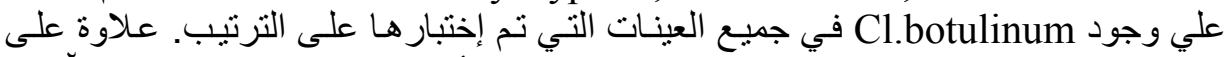

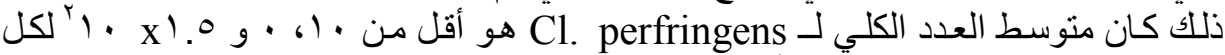

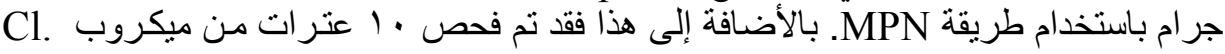
perfringens

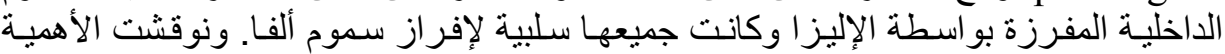

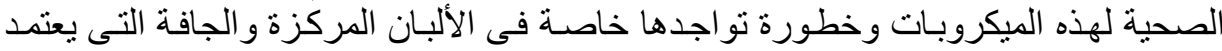

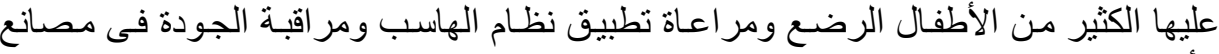

$$
\text { الأنتاج. }
$$

\section{SUMMARY}

A total of 150 random samples of evaporated; condensed and dried milk (50 samples each) were collected from dairy shops and supermarkets in Assiut city for the presence of anaerobes. By using plate method the percentages were 40,40 and $98 \%$ with an average count of $1.5 \times 10^{2} ; 4$ 
$\times 10^{3}$ and $8.5 \times 10^{2} / \mathrm{g}$; respectively. Cl.species as Cl.ramosum, Cl.perfringens, Cl.difficile Cl.innoculum, Cl.septicum, Cl.novyi type A, Cl.cadaveris and Cl.subterminale were identified in varies percentages from the evaluated samples. In addition, $\mathrm{Cl}$. perfringens was recorded in a percentage of $16 \%$ with an average count of $1.5 \times 10^{2} / \mathrm{g}$ of dried milk using MPN technique. Fortunately, Cl.botulinum failed to be detected in all examined samples. Moreover, 8 and 2 Cl.perfringens isolated, respectively from dried and evaporated milk were negative for $\alpha$-Toxin produced by $C$ l.perfringens by using Enzyme linked immunosorbent assay (ELISA). Public health as well as economical significance of detected microorganisms in the concentrated and dried milk were discussed.

Key words: Prevalence, Clostridium species, concentrated milk, dried milk, ELISA.

\section{INTRODUCTION}

The consumer awareness has played a predominant role in emphasizing the need for microbiologically safe foods for human consumption. Serious health hazards due to the presence of pathogenic microbes in milk products provide a highly favourable media for multiplication of different types of food poisoning microorganisms from different sources. The presence of anaerobes in dairy products is no assurance that they well develop but it would appear that if large numbers were involved the chance for their growth would be better than if only small numbers were included. Their presence is more difficult to control, especially in dairy industry due to several reasons. First of all it seems to be impossible to completely avoid the presence of anaerobic spores in all milk samples. Secondary, the spores are very hydrophobic and will attach to the surface of pipelines of the dairy plant, where they might multiply and repopulate. A third problem is that pasteurization heating is insufficient to kill the spores, while competition from other vegetative bacteria is eliminated (Andersson et al., 1995).

Cl.perfringens has the ability to grow at high temperatures very rapidly causing problems in foods that are not cooled quickly. Its optimum growth temperature is $43-45^{\circ} \mathrm{C}$ which has one of the fastest known growths rates for any bacterium. It has the potential to grow between 15 and $50^{\circ} \mathrm{C}$ and its vegetative cells are usually destroyed at $60^{\circ} \mathrm{C}$ and above. Spores present in food from the environment can very 
considerably in their heat resistance, surviving at temperature from 95 $100^{\circ} \mathrm{C}$ for periods of up to one hour (McClane, 1997). Enterotoxigenic Cl.perfringens strains are also associated with non-foodborne digestive diseases such as antibiotic associated diarrhoea, chronic non-foodborne diarrhoea, and some cases of sudden infant death syndrome. Immunological immaturity of some infants could lead a non-selective absorption of molecules including Cl.perfringens enterotoxin from the intestine and to a rapid transport the circulation responsible for the systemic effects of Cl.perfringens enterotoxin (Petit et al., 1999).

Currently, there is a need for a rapid, simple and sensitive serological assay for large-scale detection of Cl.perfringens enterotoxin. Enzyme-linked immunosorbent assay (ELISA) method potentially satisfy these needs, and ELISA have been developed for the specific detection of several bacterial toxins, including cholera enterotoxin, E.coli heat -labile enterotoxin, Cl.botulinum type G-toxin and Cl.difficile toxin A (McClane and Strouse, 1984).

Therefore, this work was planned to determine the rate of contamination of condensed; evaporated and dried milk with Clostridium species to explore their public health and economic importance. This include enumeration; isolation and identification of Clostridium species as well as the detection of Cl.perfringens type A enterotoxines by using Enzyme linked immunosorbent assay (ELISA).

\section{MATERIALS and METHODS}

\section{Part I: Detection of anaerobic bacteria:}

A total of 150 random samples of evaporated, condensed and dried milk (50 samples each) were purchased from dairy shops and supermarkets in Assiut city, Egypt. The samples were still valid for consumption. All samples were delivered promptly to the laboratory with a minimum of delay for bacteriological examination.

1- Dried milk samples were prepared as described by L.M.B.G. (1991).

2- Concentrated milk cans were prepared according to A.P.H.A. (1992).

\section{Bacteriological examination:-}

I- Enumeration of Clostridium species by plate method using Reinforced Clostridial agar (RCM) as described by I.C.M.S.F. (1978). Suspected colonies of characteristic shape and yellowish colour were calculated as presumptive count. 
II- Isolation of Clostridium species according to Wen and McClane (2004).

III- Enumeration of $\mathrm{Cl}$. perfringens by MPN technique using lactose sulphite broth (LSB) (Beerens et al., 1980). The counts of Cl.perfringens were recorded by using MPN Tables.

VI- Identification of isolates by:-

1- Morphological characters include: - Microscopical appearance using Gram's stain, motility test and cultural characters, where size and shape of the colonies, type of haemolysis on blood agar and change in meat particle were recorded (Holt et al., 1994).

2- Biochemical reactions include:- Sugar fermentation, indol production, changes in litmus milk, gelatin liquefaction, haemolysis on neomycin blood agar, nitrate reduction and changes in iron milk (Krieg and Holt, 1984)

3- Reaction on egg yolk media as described by Walker (1990).

Part II: Detection the enterotoxigencity of Cl.perfringens type A by using ELISA.

This part has been done in the Genetic Engineering and Molecular Biology Research Centre in Assiut University Egypt, using Bio-x Alpha toxin ELISA kit (Biok 084) (Bio-X Diagnostics-Belgique, 2008). Selected strains of the isolated Cl.perfringens from the examined samples were tested for their ability to produce enterotoxins.

\section{RESULTS}

The obtained results were recorded in Tables 1-4.

Table 1: Statistical analytical results of Clostridium species count / g of examined samples using surface plating technique.

\begin{tabular}{|l|c|c|c|c|c|}
\hline \multirow{2}{*}{ Examined samples } & \multicolumn{2}{|c|}{ Positive samples } & \multicolumn{3}{c|}{ Count / g } \\
\cline { 2 - 6 } & No./ 50 & $\%$ & Min. & Max. & $\begin{array}{c}\text { Average of } \\
+ \text { ve samples }\end{array}$ \\
\hline Evaporated milk & 20 & 40 & $*<10^{2}$ & $2.0 \times 10^{2}$ & $1.5 \times 10^{2}$ \\
\hline Condensed milk & 20 & 40 & $*<10^{2}$ & $1.1 \times 10^{4}$ & $4.0 \times 10^{3}$ \\
\hline Dried milk & 49 & 98 & $*<10^{2}$ & $8.0 \times 10^{3}$ & $8.5 \times 10^{2}$ \\
\hline
\end{tabular}

* Colonies could not be detected on the plates. 
Table 2: Incidence of different Clostridium species in the examined samples using surface plating technique.

\begin{tabular}{|l|c|c|c|c|c|c|}
\hline \multirow{2}{*}{ Clostridium species } & \multicolumn{2}{|c|}{ Evaporated milk } & \multicolumn{2}{c|}{ Condensed milk } & \multicolumn{2}{c|}{ Dried milk } \\
\cline { 2 - 8 } & \multicolumn{2}{|c|}{ Positive samples } & \multicolumn{2}{c|}{ Positive samples } & \multicolumn{2}{c|}{ Positive samples } \\
\cline { 2 - 8 } Cl. ramosum & 5 & 10 & 3 & 6 & 15 & 30 \\
\hline Cl. perfringens & - & - & - & - & 7 & 14 \\
\hline Cl. difficile & 13 & 26 & 2 & 4 & 11 & 22 \\
\hline Cl. innoculum & 2 & 4 & 14 & 28 & 4 & 8 \\
\hline Cl. septicum & - & - & - & - & 10 & 20 \\
\hline Cl. novyi type A & - & - & - & - & 1 & 2 \\
\hline Cl. cadaveris & - & - & 1 & 2 & - & - \\
\hline Cl. sporogenes & - & - & - & - & - & - \\
\hline Cl. hastiforme & - & - & - & - & - & - \\
\hline Cl. butyricum & - & - & - & - & - & - \\
\hline Cl. subterminale & - & - & - & - & 1 & 2 \\
\hline
\end{tabular}

Table 3: Statistical analytical results of Clostridium perfringens count in the positive samples using MPN technique/g.

\begin{tabular}{|l|c|c|c|c|c|}
\hline \multirow{2}{*}{$\begin{array}{c}\text { Examined } \\
\text { samples }\end{array}$} & \multicolumn{2}{|c|}{$\begin{array}{c}\text { Positive } \\
\text { samples }\end{array}$} & \multicolumn{3}{c|}{ Count /g } \\
\cline { 2 - 6 } & No./50 & $\%$ & Min. & Max. & $\begin{array}{c}\text { Average of +ve } \\
\text { samples }\end{array}$ \\
\hline Evaporated milk & 2 & 4 & $<10$ & $<10$ & $<10$ \\
\hline Condensed milk & - & - & - & - & - \\
\hline Dried milk & 8 & 16 & $<10$ & $1.1 \times 10^{3}$ & $1.5 \times 10^{2}$ \\
\hline
\end{tabular}


Table 4: Detection of Alpha Toxin by Elisa in the examined samples.

\begin{tabular}{|l|c|c|c|c|c|}
\hline \multirow{2}{*}{$\begin{array}{c}\text { Examined } \\
\text { samples }\end{array}$} & \multirow{2}{*}{$\begin{array}{c}\text { No. of } \\
\text { examined } \\
\text { samples }\end{array}$} & \multicolumn{2}{|c|}{ Positive $\alpha$-Toxin } & \multicolumn{2}{c|}{ Negative $\alpha$-Toxin } \\
\cline { 3 - 6 } & No. & $\%$ & No. & $\%$ \\
\hline Dried milk & 8 & 0 & 0 & 8 & 100 \\
\hline Evaporated milk & 2 & 0 & 0 & 2 & 100 \\
\hline Total & 10 & & & 10 & \\
\hline
\end{tabular}

\section{DISCUSSION}

\section{I- Enumeration of Clostridium species by using plate method technique.}

The incidence of Clostridium organisms in examined samples of evaporated milk were $40 \%$ (Table 1 ) at level varied from $<10^{2}$ to $2 \times$ $10^{2} / \mathrm{g}$ with an average count of $1.5 \times 10^{2} / \mathrm{g}$. This finding was higher than that recorded by Amer and El-Mossalami (2006); Edema and Akingbade (2007).

In case of condensed milk, the incidence of Clostridium organism was $40 \%$. The minimum count was $<10^{2} / \mathrm{g}$, a maximum was $1.1 \times 10^{4} / \mathrm{g}$ and the average count were $4 \times 10^{3} / \mathrm{g}$. These records were higher than those obtained by Mohamed (1984); Korashy and Sabreen (2001); Amer and El-Mossalami (2006). In general, sweetened condensed milk is not a sterile product, and the various methods of heat treatment used are not adequate to kill sporeforming bacteria and further processing and handling usually contribute a variety of microorganisms besides the sugar levels employed permit some types to grow if other conditions are favourable. Enough oxygen may be present in the headspace of an incompletely filled or poorly sealed container, to permit the growth of organisms able to tolerate the high osmotic pressure of the product.

Regarding dried milk, Clostridium species detected in $49(98 \%)$ samples, in count ranged from $<10^{2}$ to $8 \times 10^{3} / \mathrm{g}$ with an average value of $8.5 \times 10^{2} / \mathrm{g}$. 
Recorded results were higher than that reported by El-Bassiony and Aboul-Kheir (1983); Hafez and Ahmed (1988); El-Prince and Korashy (2003) however, lower than the recorded results by Lück et al. (1980). The microbial counts of dried milk depend upon the temperature, time of preheating of milk, evaporation process if used, contamination growth in storage tanks and pipes and method of drying and packaging process.

\section{II- Incidences of different Clostridium species:}

It is evident from the findings in Table 2, that Clostridium species were present in evaporated milk samples. The percentages of Cl.ramosum, Cl.difficile and Cl.innoculum were 10, 26 and 4\%, respectively, however, Cl.perfringens failed to be detected.

The presence of these microorganisms implies that, primary contamination of the product may have occurred at manufacturing sites which is in agreement with Mahari and Gashe (1990). They stated that contamination at factory could occur through air in the holding tank and pipes or the pasteurization room. Moreover, the clostridia spores were able to survive the temperature used for pasteurization of milk to some extent and later germinate and multiply in milk above $60^{\circ} \mathrm{C}$ (Griffiths, 1992). Furthermore, contamination of milk products could be incriminated to various roles performed by workers during milk processing (Gill et al., 1994).

In case of condensed milk, the Cl.ramosum, Cl.difficile, Cl.innoculum, and Cl.cadaveris were recovered from 3(6\%), 2(4\%), $14(28 \%)$ and $1(2 \%)$ samples, respectively. These findings are in agreement with those postulated by Amer and El-Mossalami (2006), while, Korashy and Sabreen (2001) could isolate Cl.perfringens.

Using high quality raw milk and fine clean sugar in condensed milk manufacture, good sanitation and hygiene during production, handling and storage are important to prevent the condensed milk from spoilage and to protect consumers from infection. In addition, high standard of plant hygiene is needed to avoid post-processing contamination. However, the heat treatments used in its production are insufficient to sterilize the product, so strict hygienic measures are still required. Also, the viscous nature of this product needs to be taken into account for the cleaning procedures. Finally, employment of experienced staff is necessary at all times. 
The results postulated in Table 2 indicated that incidences of Cl. ramosum, $\mathrm{Cl}$. perfringens, $\mathrm{Cl}$. difficile, $\mathrm{Cl}$. innoculum, $\mathrm{Cl}$. septicum, $\mathrm{Cl}$. novyi type $\mathrm{A}$ and $\mathrm{Cl}$. subterminale in the evaluated dried milk samples were $15(30 \%), 7(14 \%), 11(22 \%), 4(8 \%), 10(20 \%), 1(2 \%)$ and $1(2 \%)$, respectively. The results of $\mathrm{Cl}$. perfringens were in harmony with that obtained by Mahmoud (1987); Hafez and Ahmed (1988). Higher findings were recorded by Abd El-Hakiem (1992); Wahba (1997). However, lower records estimated by El-Leboudy (1985); Ahmed and Abd El-Gaber (1994); Saad (1995). With regard to Cl. cadaveris higher finding was detected by Hafez and Ahmed (1988).

The presence of $\mathrm{Cl}$. perfringens in milk powder may be attributed to contaminated raw milk used. Also, the incidence of such organisms in dried milk reflect the hygienic measures applied during production, handling, manufacturing and distribution and these products are considered to be of poor quality or even unfit for human consumption. Furthermore, the presence of such organisms in large numbers may constitute a public health hazard.

\section{III- Incidence and count of $\boldsymbol{C l}$. perfringens using MPN technique.}

It is apparent from the recorded data in Table 3 that; two samples (4\%) of evaporated milk were contaminated with $\mathrm{Cl}$. perfringens in count less than $10 / \mathrm{g}$. This was nearly parallel to that reported by Amer and El-Mossalami (2006). However, Edema and Akingbade (2007) indicated higher result. In contrast, Cl.perfringens failed to be detected in condensed milk which was in agreement with Amer and ElMossalami (2006). Higher incidence was estimated by Korashy and Sabreen (2001).

Furthermore, in dried milk the concerning organism was detected in $8(16 \%)$ of the examined samples in counts ranged from $<10$ to $1.1 \times$ $10^{3}$ with an average of $1.5 \times 10^{2} / \mathrm{g}$. With regard to the count obtained, it was higher than that registered by Lück et al. (1980); Hafez and Ahmed (1988); Abd El-Hakiem (1992); Ahmed and Abd El-Gaber (1994); Saad (1995).

IV- Detection of Clostridium perfringens type A enterotoxins by using enzyme linked immunosorbent assay (ELISA).

It is often difficult to distinguish Cl.perfringens food poisoning without laboratory evidence, bacteriological examination are usually employed to diagnose this food poisoning. Since up to $95 \%$ of normal adults have Cl.perfringens in their faecal flora. Its isolation without 
epidemiological or other support is not sufficient for diagnosis. Currently, it is desirable to develop more rapid and convenient method for diagnosis of Cl.perfringens food poisoning. Several methods of its enterotoxins detection have been reported, but none has yet been extensively used for the investigation of food-borne disease outbreaks, this is at least partially due to the inconvenience of these assays for large scale application. Additionally, some assays are unsatisfactory for investigation food-borne disease, owing to interference by faecal material (McClane and McDonel, 1981). Elisa procedures are rapid, specify and sensitive serological assays which have been used for detection of several bacterial toxin (Ketyi and Pacsa, 1980; Lewis et al., 1981; Lyerly et al., 1983).

In this study, Bio-X Alpha Toxin Elisa Kit (BioK084) was used for detection of Cl.perfringens Alpha Toxin in culture supernatants. It is produced in varying amount by all biotypes (A, B, C, D, and E) of Cl.perfringens and considered a primary virulence factor involved in Clostridial myonecrosi (Table 4).

Alpha Toxin is the only lethal protein produced during vegetative growth of type A strains, the most ubiquitous $C$ l.perfringens biotype that is commonly found in soil and normal intestinal flora of humans and animals. Due to its rule in gas gangrene, food poisoning and animal enterotoxima Cl.perfringens type A strain, particularly the Alpha Toxin have been the subject of intense investigations over the past 60 years (McDonel, 1986).

\section{REFERENCES}

A.P.H.A. "American Public Health Association" (1992): Standard Method for the Examination of Dairy Products. $16^{\text {th }}$ ed., American Public Health Association, Washington, D. C.

Abd El-Hakiem, E.H. (1992): Incidence and public health importance of some food poisoning organisms in milk and some milk products. Ph. D. Thesis, Fac. Vet. Med., Suez Canal Univ.

Ahmed, H.F. and Abd El-Gaber, G. (1994): Occurrence of Cl. perfringens in some imported dairy products with consideration to some plating media used for its enumeration. $6^{\text {th }}$ Sci. Cong., Fac. Vet. Med., Egypt: 62-70. 
Amer, A.A. and El-Mossalami, Hanaa, H. (2006): Quality assessment of sweetened condensed and evaporated milks in Alexandria Governorate. Assiut Vet. Med. J., 52 (108): 97-108.

Andersson, A.; Ronne, U. and Granum, P.E. (1995): What problems does the food industry have with sporeforming pathogens Bacillus cereus and Cl. perfringens? Int. J. Food Microbiol., 28: 145-155.

Beerens, H.; Romond, Ch.; Lepage, C. and Criquelion, J. (1980): A direct method for the enumeration of Cl.perfringens in foods and feces. World Congress Foodborne Infections and Intoxications. Berlin (West), 691-695.

Bio-X Diagnostics (2008): Elisa Kit for detection of Cl.perfringens. Alpha Toxin in Biological Fliuds or Culture Supernatants. Bio-X Diagnostics. Site dw comples des Postes. 94; rue J. Wauters. 5580 Jemelle-Belgique.

Edema, M.O. and Akingbade, O.A. (2007): Incidence of sporeforming bacteria in unsweetened evaporated milk brands in Nigeria. Nigerien Food J., 25(1): 138-145.

El-Bassiony, T.A. and Aboul-Kheir, F. (1983): Bacteriological evaluation of dried milk products produced in Sakha Processing Dairy Plant. Assiut Vet. Med. J., 11(21): 157-163.

El-Leboudy, Ahlam, A. (1985): Studies on sporeforming food poisoning organisms in milk and some milk products. M.V.Sc. Thesis, Fac. Vet. Med., Alexandria Univ.

El-Prince, Enas, M. and Korashy, Eman, A. (2003): Microbiological quality of dried milk-based infant foods in Assiut city. Assiut Vet. Med. J., 49 (97): 190-203.

Gill, J.P.S.; Joshi, D.V. and Kwatra, M.S. (1994): Qualitative bacteriological survey of milk and milk products with special reference to Staphylococcus aureus. Indian J. Sci., 75: 51-55.

Griffiths, M.W. (1992): Bacillus cereus in liquid milk and other milk products. Bulletin of Int. Dairy Fed., 275: 36-39.

Hafez, Ragaa, S. and Ahmed, H.F. (1988): Cl.perfringens in dried milk. Assiut Vet. Med. J., 21(41): 109-112.

Holt, J.G.; Krieg, N.R.; Sneath, P.H.; Staley, J.T. and Williams, S.T. (1994): Bergey's Manual of Determinative Bacteriology, $9^{\text {th }}$ ed., Williams and Wilkins, Baltimore.

I.C.M.S.F. "International Committee on Microbiological Specifications for Foods" (1978): Microorganisms in Foods. $2^{\text {nd }}$ ed., Vol. 2. Sampling for microbiological analysis. Principles \& specific 
applications. Univ. of Toronto, Press Toronto, Buffalo \& London.

Ketyi, I. and Pasca, A. (1980): Estimation of Vibrio cholera and E.coli heat-labile enterotoxin by enzyme linked immunosorbent assay. Acta Microbiol. Acad. Sci. Hung., 27: 89-97.

Korashy, Eman, A. and Sabreen, M.S. (2001): Incidence of aerobic and anaerobic sporeformers and thermophilic fungi in condensed milk in Assiut city. Assiut Vet. Med. J., 45(90): 157-165.

Krieg, N.R. and Holt, J.G. (1984): Bergey's Manual of Systematic Bacteriology. Williams and Wilkins, Baltimore.

L.M.B.G. (1991): Verfahren. Zur probennahme und untersuchung von Lebensmitteln. Band 1/1, Beuth Verlag. Berlin, Bonn.

Lewis, G.E.; Kulinski, S.S.; Reichard, W.S. and Metzger, J.F. (1981): Detection of Cl.botulinum type $G$ toxin by enzyme linked immunosorbent assay. Appl. Environ. Microbiol., 42: 101-1022.

Lück, H.; Jordan, I. and Dunkeld, M. (1980): Incidence of pathogens and other undesirable bacteria in milk powder. South African J. Dairy Technol., 12: 51-56.

Lyerly, D.M.; Sullivan, N.M. and Wilkins, T.D. (1983): Enzyme linked immunosorbent assay for Cl.difficile toxin A.J. Clin. Microbiol., 17: $72-78$.

Mahari, T. and Gashe, B.A. (1990): A survey of the microflora of raw and pasteurized milk and the source of contamination in a milk processing plant in Addis Ababa, Ethiopia. J. Dairy Res., 57: 233-235.

Mahmoud, H.F. (1987): Studies on Clostridia in milk and some dairy products. M.V.SC. Thesis, Fac. Vet. Med., Cairo Univ.

McClane, B.A. (1997): Cl.perfringens In Food Microbiology. Fundamentals and Frontiers. Doyle, M.P., Beuchat, L.R. and Montville, T.D. (Eds.) pp.: 305-326. ASM Press, Washington, D.C., USA.

McClane, B.A. and McDonel, J.L. (1981): Protective effects of osmotic stabilizers on morphological and permeability alterations induced in vero cells by Cl.perfringens enterotoxin. Biochem. Biophys. Acta, 641: 401-409.

McClane, B.A. and Strouse, J.R. (1984): Rapid detection of Cl.perfringens type A enterotoxin by Enzyme-Linked Immunosorbent Assay. J. Clin. Microbiol., 19(2): 112-115. 
McDonel, J.L. (1986): Toxins of Cl.perfringens types A, B, C, D and E. In: Pharmacology of Bacterial Toxins. Dorner, F. and Drews, H. (Eds.), Pegaman Press, Oxford, pp.: 477-517.

Mohamed, Seham, M. (1984): Studies on the microbiology of sweetened condensed milk. Vet. Med. J., 32 (3): 235-248.

Petit, L.; Gibet, M. and Popoff, M. (1999): Detection of enterotoxin of Cl.perfringens. In: Clostridium. Academic Press (ed.) p.: 438.

Saad, Nagah, M. (1995): Incidence of Cl.perfringens in milk powder. Assiut Vet. Med. J., 32 (64): 151-156.

Wahba, Nahad, M. (1997): Food poisoning sporeforming microorganisms in milk and some milk products. M.V.Sc. Thesis, Fac. Vet. Med., Assiut Univ.

Walker, P.D. (1990): Clostridium. In: The Diagnostic Procedures in Veterinary, Bacteriology and Mycology. $5^{\text {th }}$ ed., pp.: 229-251, Academic Press, INC., San Diego, California, USA.

Wen, Q. and McClane, B. (2004): Detection of enterotoxigenic Cl.perfringens types A isolates in American Retail Foods. J. Appl. Envrion. Microbiol., 70(5): 2685-2691. 